\title{
Colorectal Cancer pT4a TNM Finding v8
}

National Cancer Institute

\section{Source}

National Cancer Institute. Colorectal Cancer pT 4a TNM Finding v8. NCI Thesaurus. Code C134164.

Colorectal cancer with tumor invading through the visceral peritoneum (including gross perforation of the bowel through tumor and continuous invasion of tumor through areas of inflammation to the surface of the visceral peritoneum). (from AJCC 8th Ed.) 